\title{
WERYFIKACJA SKUTECZNOŚCI PREDYKCJI WYBRANYCH MODELI ANALIZY DYSKRYMINACYJNEJ NA PRZYKŁADZIE PRZEDSIĘBIORSTW FUNKCJONUJĄCYCH W SPECJALNYCH STREFACH EKONOMICZNYCH W POLSCE
}

\author{
VERIFICATION OF THE PREDICTION EFFECTIVENESS OF THE DIS- \\ CRIMINATORY MODELS BASED ON COMPANIES LOCATED IN THE \\ SPECIAL ECONOMIC ZONES IN POLAND
}

\begin{abstract}
Streszczenie: Celem artykułu jest weryfikacja skuteczności predykcji wybranych 10 modeli analizy dyskryminacyjnej na przykładzie próby 15 przedsiębiorstw funkcjonujących w specjalnych strefach ekonomicznych w Polsce. Jak wynika z przeprowadzonych badań modele poddane weryfikacji właściwie odzwierciedlały sytuację finansową badanych przedsiębiorstw. Zwrócono jednakże uwagę na konieczność dokonywania oceny sytuacji finansowej przedsiębiorstw za pomocą wielu modeli analizy dyskryminacyjnej, gdyż wskazania jednego modelu mogą prowadzić do błędnych ustaleń.
\end{abstract}

Słowa kluczowe: analiza dyskryminacyjna, sytuacja finansowa przedsiębiorstwa, modele wczesnego ostrzegania, specjalne strefy ekonomiczne w Polsce, kryzys finansowy

Received: 07.2018

\begin{abstract}
The aim of the article is to verify the effectiveness of prediction of selected 10 models of discriminant analysis on the example of a sample of 15 enterprises operating in special economic zones in Poland. At the end of the work, I have made a summary and have drawn conclusions that presented discriminatory models properly reflected financial standing of researched companies and the evaluation of the companies financial situation should be made by many methods because the indication of one model can lead to wrong decisions
\end{abstract}

Key words: discriminant analysis, financial standing of companies, methods of the early warning, special economic zones in Poland, financial crisis.

Accepted: 09.2018

\footnotetext{
Katedra Finansów, Wydział Ekonomii, Uniwersytet Rzeszowski
} 


\section{Wstęp}

Zainteresowanie problematyką prognozowania zagrożeń w funkcjonowaniu przedsiębiorstw pojawiło się w Stanach Zjednoczonych już na początku XX wieku. Szczególne nasilenie zapotrzebowania na modele predykcyjne wystąpiło w okresie wielkiego, światowego kryzysu gospodarczego na przełomie lat 20. i 30. XX w. Natomiast przełom w badaniach nastąpił w latach 60., kiedy to w Stanach Zjednoczonych wypracowane zostały przez E. Altmana modele umożliwiające szybkie wykrywanie zagrożeń w funkcjonowaniu przedsiębiorstw. Prace E. Altmana zapoczątkowały dynamiczny rozwój dyskryminacyjnych modeli wczesnego ostrzegania i stały się inspiracją do różnorodnych poszukiwań nowych rozwiązań w tej dziedzinie [Mączyńska 2003, 111].

Ocena sytuacji finansowej przedsiębiorstwa ma olbrzymie znaczenie dla właścicieli, w tym akcjonariuszy, którzy ulokowali swój kapitał, by osiągnąć w przyszłości zwrot na zakładanym poziomie, kadry zarządzającej, która podejmuje decyzje w ramach prowadzonej działalności, instytucji finansowych, które udzielają pożyczek lub kredytów, czy też rad nadzorczych. W literaturze przedmiotu zostało zaprezentowanych wiele metod analizy ekonomicznej, które mogą posłużyć do oceny sytuacji finansowej przedsiębiorstwa, np. analiza pionowa i pozioma bilansu oraz rachunku zysków i strat, analiza wskaźnikowa, analiza dyskryminacyjna, analiza logitowa, czy liczne modyfikacje punktowej metody oceny ryzyka. Wymienione metody różnią się od siebie pod względem złożoności obliczeń, ale i możliwości interpretacyjnych [Siemińska 2003, 72-83, 97-138; Kowalak 2003, 49-83, 181-192; Zaleska 2005, 53-61, 62-91, 133-135; Bień 2011, 97-118].

Celem artykułu jest weryfikacja skuteczności predykcji wybranych 10 modeli analizy dyskryminacyjnej na przykładzie próby 15 przedsiębiorstw funkcjonujących w specjalnych strefach ekonomicznych w Polsce. Badania dotyczą lat 2004-2010. 


\section{Modele analizy dyskryminacyjnej}

W Polsce stworzono kilkadziesiąt modeli dyskryminacyjnych, przy czym pierwszy model został opracowany przez prof. Elżbietę Mączyńską w 1994 r. W literaturze przedmiotu często przypisuje się, w sposób nieuprawniony z metodycznego punktu widzenia, walor uniwersalności (pomija się nieporównywalne warunki gospodarowania i specyfikę branżową przedsiębiorstw zaliczonych do próby uczącej modelu) oraz niezmiennej wiarygodności diagnostycznej, bez względu na upływ czasu od ich opublikowania. Dlatego też celowe jest okresowe przeprowadzanie wiarygodności diagnostycznej modeli oceny kondycji finansowej [Kitowski 2013, 156].

Metody analizy dyskryminacyjnej są pozbawione zasadniczej wady analizy wskaźnikowej, jaką jest trudność w jednoznacznej ocenie sytuacji finansowej przedsiębiorstwa. Wykorzystanie wielu wskaźników często zaciemnia obraz sytuacji przedsiębiorstwa, co powoduje konieczność ich selekcji. Z drugiej strony selekcja taka grozi subiektywizmem. Rozwiązaniem tego problemu są właśnie modele dyskryminacyjne, które sprowadzając ocenę sytuacji finansowej do jednej wartości liczbowej wykluczają tym samym sprzeczności interpretacyjne [Bombiak 2010, 144-145]. Nie bez znaczenia jest też trend danej funkcji w kolejnych latach. Gdy wartości danej funkcji corocznie zmniejszają się, pomimo że wartość funkcji wskazuje na przedsiębiorstwo o dobrej sytuacji (np. z>0 w modelu A. Hołdy) [Hołda 2001, 306310], oznacza to, że sytuacja finansowa ulega pogorszeniu. Niewątpliwie największą zaletą tych modeli jest prostota ich wykorzystania [Zielińska Sitkiewicz 2012, 300].

W pracy zastosowano kilka modeli analizy dyskryminacyjnej, które zostały zaprezentowane w tabeli 1.

Tabela 1. Wybrane funkcje dyskryminacyjne

Table 1. Selection methods of discriminant analysis

\begin{tabular}{|c|l|}
\hline Autor modelu & \multicolumn{1}{|c|}{ Postać modelu } \\
\hline E. Mączyńska & $\mathrm{W}=1,50 * \mathrm{~W}_{1}+0,08 * \mathrm{~W}_{2}+10,0 * \mathrm{~W}_{3}+5,00 * \mathrm{~W}_{4}+0,30 * \mathrm{~W}_{5}+0,10 *$ \\
[Mączyńska 1994, 42-45] & $\mathrm{W}_{6}$, gdzie: \\
\hline
\end{tabular}


Weryfikacja skuteczności predykcji wybranych modeli analizy dyskryminacyjnej na przykładzie przedsiębiorstw funkcjonujących w specjalnych strefach ekonomicznych w Polsce

\begin{tabular}{|c|c|}
\hline & W<0, przedsiębiorstwo zagrożone upadłością, \\
\hline $\begin{array}{l}\text { R. Jagiełło - Model dyskry- } \\
\text { minacyjny dla małych i } \\
\text { średnich przedsiębiorstw z } \\
\text { sektora "Przemysł” [Jagiełło } \\
2013,66 \text { ] }\end{array}$ & $\begin{array}{l}W=-1,8603+12,296 * W_{5}+0,1675 * W_{9}+1,399 * W_{13} \text {, gdzie: } \\
W<0 \text {, istnieje wysokie prawdopodobieństwo zaklasyfikowa- } \\
\text { nia tej firmy w ciągu kolejnego roku do kategorii zagrożo- } \\
\text { nych, }\end{array}$ \\
\hline $\begin{array}{l}\text { A.Hołda } \\
\text { [Hołda 2001, 306-310] }\end{array}$ & $\begin{array}{l}W=0,605+0,681 * W_{1}-0,0196 * W_{2}+0,00969 * W_{3}+ \\
0,000672 * W_{4}+0,157 * W_{5} \text {, gdzie: } \\
W<0 \text {, jednostka klasyfikowana jest jako bankrut; }\end{array}$ \\
\hline $\begin{array}{l}\text { J. Gajdka, D. Stos } \\
\text { [Gajdka, Stos 1996, 56-63] }\end{array}$ & $\begin{array}{l}W=07732059-0,0856425 * W_{1}+0,0007747 * W_{2} \\
+0,9220985 * W_{3}+0,6535995 * W_{4}-0,594687 * W_{5} \text {, gdzie: } \\
W<0,45 \text {, podmiot należy zaliczyć do „zbankrutowanych”; }\end{array}$ \\
\hline $\begin{array}{l}\text { B. Prusak [Prusak 2004, } \\
\text { 165-179] }\end{array}$ & $\begin{array}{l}W=-1,568492770195 \\
+6,5244812965393 * W_{1}+0,147970467805862 * W_{2} \\
+0,406149059534073 * W_{3}+2,17539358139038 * W_{4} \text {, gdzie: } \\
W<-0,129932582, \text { przedsiębiorstwo zaliczane do bankru- } \\
\text { tów, }\end{array}$ \\
\hline $\begin{array}{l}\text { Model (G) INE PAN } \\
\text { [Mączyńska 2004, 107-117] }\end{array}$ & $\begin{array}{l}W=9,498 * W_{1}+3,566 * W_{2}+2,903 * W_{3}+0,452 * W_{4}-1,498 \\
\text { gdzie: } \\
W<0 \text {, przedsiębiorstwo zagrożone upadłością; }\end{array}$ \\
\hline $\begin{array}{l}\text { M. Hamrol, B. Czajka, M. } \\
\text { Piechocki } \\
\text { [Hamrol i inni 2004, 35-39] }\end{array}$ & $\begin{array}{l}W=3,562 * \mathrm{~W}_{7}+1,588 * \mathrm{~W}_{16}+4,288 * \mathrm{~W}_{5}+6,719 * \mathrm{~W}_{13}- \\
2,368 \\
\text { gdzie: } \\
W<=0 \text {, analizowana jednostka jest kandydatem do rychłego } \\
\text { bankructwa; }\end{array}$ \\
\hline $\begin{array}{l}\text { D. Hadasik } \\
\text { [Hadasik 1998, 72-79 i 159] }\end{array}$ & $\begin{array}{l}W=0,335969 * W_{1}-0,71245 * W_{2}-2,4716 * W_{5}+1,46434 * W_{7}+ \\
0,00246069 * W_{9}-0,0138937 * W_{12}+0,0243387 * W_{17} \\
+2,59323\end{array}$ \\
\hline
\end{tabular}




\begin{tabular}{|c|c|}
\hline & $\begin{array}{l}\text { gdzie: } \\
\text { W<= - 0,42895, przedsiębiorstwa zagrożone upadłością; }\end{array}$ \\
\hline $\begin{array}{l}\text { D. Appenzeller, K. Szarzec } \\
\text { [Appenzeller, Szarzec 2004, } \\
\text { 120-128] }\end{array}$ & $\begin{array}{l}W=\quad 0,819138 * W_{1}+2,56661 * W_{2}-0,00500208 * W_{3}+ \\
0,000628865 * W_{4}-0,00951358 * W_{5}-0,556326 \\
\text { gdzie: } \\
W<0 \text {, spółka zagrożona upadłością; }\end{array}$ \\
\hline $\begin{array}{l}\text { T. Maślanka [Maślanka } \\
\text { 2008, 193-254] }\end{array}$ & $\begin{array}{l}W=-1,44979+3,55401 * W_{4}+2,14847 * W_{6}-0,33302 * W_{7}+ \\
4,81862 * W_{17}+0,05236 * W_{26}+2,52164 * W_{40} \\
\text { gdzie: } \\
W=0, \text { wielkość graniczna; }\end{array}$ \\
\hline
\end{tabular}

Źródło: opracowanie własne.

\section{Ocena kondycji finansowej spółek}

Poniżej w tabeli 2 zaprezentowane zostały wyniki oceny kondycji finansowej 3 spółek o najsłabszej sytuacji finansowej spośród 15 podlegających badaniu. ${ }^{\dagger}$ Ocena została dokonana za pomocą metod wskazanych w tabeli 1.

Tabela 2. Wyniki poszczególnych modeli dyskryminacyjnych dla wybranej próby przedsiębiorstw w latach 2004-2010

Table 2. Results of individual discriminant models for a selected sample of enterprises in 2004-2010

\begin{tabular}{|l|l|l|l|l|l|l|l|}
\hline Model/ Autor modelu & 2004 & 2005 & 2006 & 2007 & 2008 & 2009 & 2010 \\
\hline \multicolumn{10}{|c|}{ Sanglass S.A. } \\
\hline
\end{tabular}

† Z uwagi na fakt, że tabela zawierająca wyniki 15 przedsiębiorstw byłaby bardzo obszerna, dlatego też zaprezentowano wyłącznie wyniki spółek, dla których odnotowano co najmniej 15 wskazań ujemnych, a więc sugerujących zagrożenie upadłością. 
Weryfikacja skuteczności predykcji wybranych modeli analizy dyskryminacyjnej na przykładzie przedsiębiorstw funkcjonujących w specjalnych strefach ekonomicznych w Polsce

\begin{tabular}{|c|c|c|c|c|c|c|c|}
\hline R. Jagiełło & 3,38 & 0,86 & $-0,61$ & $-2,19$ & $-0,80$ & $-0,66$ & $-0,23$ \\
\hline Model G INE PAN & 7,05 & 2,03 & 0,86 & $-0,35$ & 0,00 & 0,32 & 0,79 \\
\hline $\begin{array}{l}\text { M. Hamrol, B. Czajka, M. Pie- } \\
\text { chocki }\end{array}$ & 16,54 & 1,75 & 0,01 & 0,44 & 0,70 & 0,54 & 0,34 \\
\hline D. Hadasik & $-1,68$ & 0,06 & $-0,24$ & 0,04 & $-0,09$ & $-0,19$ & $-0,10$ \\
\hline D. Appenzeller, K. Szarzec & 7,46 & 0,12 & $-0,25$ & $-0,39$ & $-0,27$ & $-0,27$ & $-0,15$ \\
\hline T. Maślanka & 1,78 & 0,48 & $-0,37$ & $-0,74$ & $-0,60$ & $-0,72$ & $-0,40$ \\
\hline E. Mączyńska & 4,72 & 2,63 & 0,69 & $-1,05$ & $-0,50$ & 0,48 & 0,90 \\
\hline B. Prusak & 7,84 & 0,05 & $-0,85$ & $-1,55$ & $-0,76$ & $-0,86$ & $-0,62$ \\
\hline \multicolumn{8}{|c|}{ Vogel Noot Packaging Polska S.A. } \\
\hline R. Jagiełło & $-0,86$ & $-0,39$ & $-0,73$ & $-5,94$ & $-3,13$ & $-1,07$ & $-2,30$ \\
\hline Model G INE PAN & 1,52 & 1,63 & 0,94 & $-5,27$ & $-0,67$ & 0,29 & $-0,24$ \\
\hline $\begin{array}{l}\text { M. Hamrol, B. Czajka, M. Pie- } \\
\text { chocki }\end{array}$ & 1,48 & 1,58 & 1,18 & $-5,28$ & $-1,29$ & 0,69 & 0,09 \\
\hline D. Hadasik & 0,18 & $-0,03$ & 0,15 & $-0,34$ & $-1,39$ & $-0,92$ & $-0,88$ \\
\hline D. Appenzeller, K. Szarzec & 0,07 & 0,07 & $-0,40$ & $-5,19$ & $-0,62$ & $-0,21$ & 0,22 \\
\hline A. Hołda & 0,83 & 0,84 & 0,84 & - & - & - & - \\
\hline J. Gajdka, D. Stos & 0,20 & 0,21 & 5,27 & - & - & - & - \\
\hline T. Maślanka & 0,74 & 0,94 & 0,62 & $-2,73$ & $-1,01$ & $-0,48$ & $-0,80$ \\
\hline E. Mączyńska & 0,56 & 0,50 & $-0,45$ & $-13,76$ & $-2,64$ & 0,52 & $-0,38$ \\
\hline B. Prusak & $-0,57$ & $-0,42$ & $-0,98$ & $-6,35$ & $-1,47$ & $-0,83$ & $-1,39$ \\
\hline \multicolumn{8}{|c|}{ Zakład Produkcyjny „Kamot - Mielec” S.A. } \\
\hline R. Jagiełło & $-0,24$ & $-1,84$ & $-0,39$ & $-0,30$ & $-0,29$ & $-2,93$ & $-12,05$ \\
\hline Model G INE PAN & 2,73 & 0,48 & 2,44 & 2,93 & 2,63 & 0,21 & $-1,10$ \\
\hline
\end{tabular}




\begin{tabular}{|c|c|c|c|c|c|c|c|}
\hline $\begin{array}{l}\text { M. Hamrol, B. Czajka, M. Pie- } \\
\text { chocki }\end{array}$ & 2,89 & 1,76 & 3,21 & 3,36 & 2,80 & 4,68 & $\begin{array}{r}109,4 \\
7\end{array}$ \\
\hline D. Hadasik & 3,76 & $-1,60$ & 4,43 & - & & - & - \\
\hline D. Appenzeller, K. Szarzec & 0,69 & 0,37 & 0,75 & 0,73 & 0,48 & 1,43 & $-41,19$ \\
\hline A. Hołda & 1,10 & 1,05 & 1,32 & 1,38 & 1,10 & 2,53 & 3,13 \\
\hline J. Gajdka, D. Stos & 0,21 & 0,06 & 0,21 & 0,14 & 0,15 & 0,05 & $-8,02$ \\
\hline T. Maślanka & 1,66 & 0,08 & 1,60 & 1,99 & 1,75 & $-1,75$ & $-0,78$ \\
\hline E. Mączyńska & 1,67 & $-0,90$ & 0,97 & 1,48 & 1,28 & $-1,53$ & $-76,87$ \\
\hline B. Prusak & 0,04 & $-1,11$ & $-0,17$ & 0,37 & 0,03 & $-0,99$ & $-37,40$ \\
\hline
\end{tabular}

Źródło: opracowanie własne. Obliczenia funkcji zostały skorygowane tak (poprzez odpowiednią korektę wyrazu wolnego), by wartością graniczną poszczególnych funkcji było 0 . Dlatego też należy przyjąć, że w przypadku, gdy wartość funkcji jest mniejsza od zera, wówczas przedsiębiorstwo jest zagrożone upadłością.

Jak wynika z dokonanych obliczeń metody poddane weryfikacji w zdecydowanej większości wskazały zmiany kondycji finansowej poszczególnych przedsiębiorstw. Należy bowiem pamiętać, że wzrost wartości funkcji oznacza polepszenie kondycji finansowej przedsiębiorstwa, natomiast zmniejszenie wartości funkcji to pogorszenie się sytuacji finansowej. Jednocześnie analiza wyników funkcji dyskryminacyjnych wskazuje, że przedsiębiorstwa w okresie objętym badaniem odznaczały się w większości dobrą kondycją finansową. Dokonując analizy kondycji finansowej przedsiębiorstw w poszczególnych latach zauważalne jest jednak pogorszenie się sytuacji 9 z 15 omawianych przedsiębiorstw w latach 2009 i 2010, co prawdopodobnie związane było z kryzysem ogólnoświatowym.

W przypadku próby piętnastu przedsiębiorstw:

- 13 firm odznaczało się niezagrożoną kondycją finansową. O dobrej kondycji finansowej świadczy fakt, że wartości funkcji dyskryminacyjnych w latach 2004-2010 przyjmowały wartości dodatnie lub też zdarzyły się sporadycznie wyniki ujemne. Na 15 przedsiębiorstw pod- 
legających próbie badawczej: 9 odnotowało od 0 do 5 wskazań ujemnych sugerujących zagrożenie upadłością, 1 odnotowało 6 wskazań ujemnych, 3 odnotowały od 10 do 15 wskazań ujemnych. Należy jednak zauważyć, że w latach 2009-2010 sytuacja finansowa 8 ze wskazanych powyżej 13 przedsiębiorstw pogorszyła się. Pomimo że wyniki funkcji dyskryminacyjnych przyjmowały wartości dodatnie to jednak były one niższe niż w latach 2004-2008.

- 2 firmy miały słabą sytuację finansową.

- Vogel Noot Packaging Polska S.A. W latach 2004-2006 przedsiębiorstwo odznaczało się dobrą kondycją finansową, w 2006 r. zauważalny jest spadek wartości funkcji w stosunku do lat 2004 i 2005 co oznacza, że sytuacja finansowa przedsiębiorstwa uległa pogorszeniu. W latach 2007-2010 wartości funkcji były w większości ujemne, co oznacza, że przedsiębiorstwo było zagrożone upadłością. Warto podkreślić, że w latach 2006 - 2008 i 2010 Spółka odnotowała stratę na działalności operacyjnej i stratę netto.

- Sanglass S.A. Sytuacja spółki w latach 2004 - 2005 była stabilna, natomiast w latach 2006-2010 uległa znacznemu pogorszeniu. W latach 2006-2010 większość funkcji osiągnęła wartości ujemne, co oznacza, że Spółka była zagrożona upadłością.

Biorąc pod uwagę wyniki modeli w ramach poszczególnych przedsiębiorstw należy stwierdzić, iż wystąpiły sytuacje gdzie większość modeli wskazało na niezagrożoną sytuację finansową natomiast pozostałe na ryzyko bankructwa, np.

- modele R. Jagiełło i B. Prusaka w firmie Cebal Tuba Sp. z o.o. w latach 2005-2008,

- model B. Prusaka w firmie Dezamet S.A. w latach 2005-2010,

- model B. Prusaka w firmie Sanfarm Sp. z o.o. w 2005 r.,

lub odmiennie, tzn. większość modeli wskazała na ryzyko upadłości natomiast pozostałe na niezagrożoną sytuację, np.

- model M. Hamrola, B. Czajki i M. Piechockiego (model poznański) w firmie Sanglass S.A. w latach 2006-2010, 
- model A. Hołdy w firmie Kamot - Mielec S.A. w 2010 r.,

- modele M. Hamrola, B. Czajki i M. Piechockiego oraz D. Appenzeller i K. Szarzec w firmie Vogel Noot Packaging Polska S.A. w 2010 r.

Analizując wartości otrzymanych funkcji dla wszystkich przedsiębiorstw zauważamy, że największą ilość wartości ujemnych w danym roku wykazały:

- w 2004 r. model R. Jagiełły - 5 wskazań z 10 wartości ujemnych ogółem,

- w 2005 r. model B. Prusaka - 6 wskazań z 16 wartości ujemnych ogółem,

- w 2006 r. model B. Prusaka - 5 wskazań z 15 wartości ujemnych ogółem,

- w 2007 r. model R. Jagiełły - 6 wskazań z 24 wartości ujemnych ogółem,

- w 2008 r. model R. Jagiełły - 7 wskazań z 24 wartości ujemnych ogółem,

- w 2009 r. model R. Jagiełły - 6 wskazań z 18 wartości ujemnych ogółem,

- w 2010 r. model R. Jagiełły i model B. Prusaka - 6 wskazań z 26 wartości ujemnych ogółem.

Z przeprowadzonych obliczeń wynika, że wysoką odmienność w odniesieniu do pozostałych metod wykazały modele B. Prusaka i R. Jagiełły. Gdyby obliczenia zostały dokonane wyłącznie za pomocą tych dwóch metod to okazałoby się, że zagrożone upadłością było sześć przedsiębiorstw. Nasuwa się zatem wniosek, że dokonanie oceny kondycji finansowej przedsiębiorstwa za pomocą jednego czy też dwóch modeli może prowadzić do błędnych ustaleń.

Jak wynika z przeprowadzonej analizy niejednolitość wskazań związana jest z różnorodnością wskaźników użytych do konstrukcji danego modelu oraz ilością wskaźników analizy finansowej użytych do konstrukcji modelu. Poza tym autorzy konstruując swoje modele dokonywali ich weryfikacji na próbach określonych przedsiębiorstw. Może więc zdarzyć się sytuacja, że oceniane przedsiębiorstwo nie jest dopasowane do pierwotnej próby badawczej stąd rozbieżność wyników. 


\section{Podsumowanie}

Na podstawie przeprowadzonych badań można stwierdzić, że zaprezentowane modele dyskryminacyjne dobrze odwzorowują sytuację finansową firm bowiem przedsiębiorstwa objęte próbą badawczą w dalszym ciągu funkcjonują i nie ogłoszono wobec nich upadłości. Należy jednak zwrócić uwagę, że niektóre modele wskazywały na dobrą sytuację finansową firmy, podczas gdy inne na słabą sytuację finansową, np. model M. Hamrola, B. Czajki i M. Piechockiego zastosowany do oceny Sanglass S.A. Potwierdza to tezę, że nie należy dokonywać oceny sytuacji finansowej przedsiębiorstwa za pomocą jednego modelu lub jednej metody[Lichota 2009, 31]. Przeprowadzenie skutecznej analizy sytuacji finansowej w oparciu o modele dyskryminacyjne wiąże się z koniecznością zastosowania co najmniej kilku modeli. Pozwoli to na „odrzucenie” wyników modelu, który nie sprawdza się w przypadku danego przedsiębiorstwa. Dokonując wyboru metody do oceny kondycji finansowej przedsiębiorstw należy również zwrócić uwagę, by dany model był dopasowany branżowo, co ograniczy ryzyko błędnego przyporządkowania modelu. Jak wspomniano we wstępie nie należy bezkrytycznie ufać wynikom modeli dyskryminacyjnych. Mogą one jedynie wspomagać decyzje podejmowane w przedsiębiorstwie.

Na podstawie przeprowadzonych badań stwierdzono pogorszenie się sytuacji 9 z 15 omawianych przedsiębiorstw w latach 2009 i 2010, co zapewne związane było z kryzysem ogólnoświatowym.

Na zakończenie warto podkreślić, że należy być ostrożnym podczas wydawania ocen dotyczących sytuacji finansowej przedsiębiorstw bowiem nie wszystkie jednostki, które wykazują straty finansowe są w złej kondycji finansowej. Istnieją przedsiębiorstwa, które poprzez zakupywanie materiałów w macierzystych centralach zagranicznych celowo zawyżają koszty i wykazują straty na działalności [Wilczyński 2000, 17]. Wystąpić może również sytuacja odwrotna. Modele dyskryminacyjne uwzględniają w większości dane pochodzące z bilansu i rachunku zysków i strat. Wyprzedaż majątku powodująca krótkotrwały przyrost gotówki, spłatę zobowiązań, malejący poziom zapasów a także sprytne zabiegi księgowe mogą dać nieprawdziwy obraz kondycji finansowej przedsiębiorstw. 


\section{Bibliografia}

Appenzeller D., Szarzec K., Prognozowanie zagrożenia upadłościq polskich spółek publicznych, „Rynek Terminowy”, nr 1/2004, s. 120-128.

Bień W., Zarządzanie finansami przedsiębiorstwa, Difin, Warszawa 2011

Bombiak E., Modele dyskryminacyjne jako metoda oceny sytuacji finansowej przedsiębiorstwa, Zeszyty Naukowe Akademii Podlaskiej w Siedlcach Nr 86, Siedlce 2010.

Gajdka J., Stos D., Wykorzystanie analizy dyskryminacyjnej w ocenie kondycji finansowej przedsiębiorstw, (w:) Restrukturyzacja w procesie przekształceń i rozwoju przedsiębiorstw, red. R. Borowiecki, Wydawnictwo Akademii Ekonomicznej, Kraków 1996.

Hadasik D., Upadłość przedsiębiorstw w Polsce i metody ich prognozowania, Zeszyty Naukowe Akademii Ekonomicznej w Poznaniu seria II nr 153, Poznań 1998.

Hamrol M., Czajka B., Piechocki M., Upadłość przedsiębiorstwa-model analizy dyskryminacyjnej, „Przegląd Organizacji”, nr 6/2004, s. 35-39.

Hołda A., Prognozowanie bankructwa jednostki w warunkach gospodarki polskiej z wykorzystaniem funkcji dyskryminacyjnej ZH, „Rachunkowość”, nr 5/2001,s. 306310.

Jagiełło R., Analiza dyskryminacyjna i regresja logistyczna w procesie oceny zdolności kredytowej przedsiębiorstw, „Materiały i Studia”, NBP, nr 286/2013, s. 66.

Kitowski J., Sposoby ujmowania kryterium uwarunkowań działalności w metodach oceny kondycji finansowej przedsiębiorstwa, Zeszyty Naukowe Uniwersytetu Szczecińskiego, Finanse, Rynki Finansowe, Ubezpieczenia nr 59, Szczecin 2013.

Kowalak R., Ocena kondycji finansowej przedsiębiorstwa, Wydawnictwo Ośrodka Doradztwa i Doskonalenia Kadr, Gdańsk 2003

Lichota W., Metody wczesnego ostrzegania o zmianach sytuacji finansowej przedsiębiorstw, „Wiadomości Statystyczne”, nr 10/2009, s. 24-34.

Maślanka T., Przepływy pieniężne w zarzqdzaniu finansami przedsiębiorstw, Wydawnictwo C.H. Beck, Warszawa 2008.

Mączyńska E., Globalizacja ryzyka a systemy wczesnego ostrzegania przed upadłościq przedsiębiorstw, (w:) Upadłość przedsiębiorstw w Polsce w latach 1990-2003. Teoria i praktyka, red. D. Appenzeller, Wydawnictwo Akademii Ekonomicznej w Poznaniu, Poznań.2004.

Mączyńska E., Ocena kondycji przedsiębiorstwa (Uproszczone metody), „Życie Gospodarcze", nr 38/1994, s. 42-45. 
Mączyńska E., Systemy wczesnego ostrzegania przed upadłościq przedsiębiorstw standardem europejskim, (w:) Polskie przedsiębiorstwa wobec standardów europejskich, red. K. Kuciński, „Materiały i Prace Instytutu Funkcjonowania Gospodarki Narodowej", Szkoła Główna Handlowa, Warszawa 2003, t. 84.

Prusak B., Ocena zagrożenia upadłościq produkcyjnych spółek kapitałowych w Polsce w latach 1998-2002, (w:) Upadtość przedsiębiorstw w Polsce w latach 19902003. Teoria i praktyka, red. D. Appenzeller, „Zeszyty Naukowe Akademii Ekonomicznej w Poznaniu" nr 49, Poznań 2004.

Siemińska E., Finansowa kondycja firmy. Metody pomiaru i oceny, Wydawnictwo Poltext, Warszawa 2003

Wilczyński W.: Niedoceniane zagrożenia, „Nowe Życie Gospodarcze”, nr 3/2000 r., s. 17.

Zaleska M., Ocena ekonomiczno-finansowa przedsiębiorstwa przez analityka bankowego, Wydawnictwo Szkoły Głównej Handlowej w Warszawie, Warszawa 2003

Zielińska - Sitkiewicz M., Zastosowanie metod wielowymiarowej analizy dyskryminacyjnej do oceny kondycji firm deweloperskich, (w:) Modele ilościowe w badaniach ekonomicznych, red. B. Borkowski, Tom XIII/3, Szkoła Główna Gospodarstwa Wiejskiego, Warszawa 2012. 